J. Dairy Sci. 96:7731-7738

http://dx.doi.org/10.3168/jds.2013-6736

(C) American Dairy Science Association ${ }^{\circledR}, 2013$.

\title{
Short communication: Comparison of ambient temperature, relative humidity, and temperature-humidity index between on-farm measurements and official meteorological data
}

\author{
L. K. Schüller, O. Burfeind, and W. Heuwieser ${ }^{1}$ \\ Clinic for Animal Reproduction, Faculty of Veterinary Medicine, Freie Universität Berlin, Koenigsweg 65, 14163 Berlin, Germany
}

\begin{abstract}
The objectives of the study were to compare the climate conditions of 7 dairy farms with the climate recorded at the closest official meteorological station. Specifically, we set out to compare the ambient temperature, relative humidity, and the resulting temperaturehumidity index (THI) from 7 different barns with those data obtained from the closest official meteorological stations and to compare the climate conditions between 4 different locations within 1 barn. Measures of correlation and agreement demonstrated that climate conditions differ significantly between the barn and the corresponding official meteorological stations as well as between 4 different locations inside 1 barn. The ambient temperature was higher $\left(6.4 \pm 3.6^{\circ} \mathrm{C}\right)$ in the barn than at the official meteorological station. The relative humidity was higher at the official meteorological station $(0.2 \pm 7.2 \%)$ than in the barn. The THI was higher $(11.1 \pm 6.5)$ in the barn than at the official meteorological station. Days with an average THI $\geq$ 72 were 64 and 4 out of 756 experimental d in the barn and at the official meteorological station, respectively. Also, in a comparison of 7 different barns, ambient temperature and THI were significantly higher than at the closest corresponding official meteorological station. These results indicate that climate conditions should be obtained from on-farm measurements to evaluate potential heat stress and to develop effective measures to abate heat stress of dairy cows.
\end{abstract}

Key words: dairy cow, heat stress, climate, temperature-humidity index

\section{Short Communication}

In the last $50 \mathrm{yr}$, annual milk yield per cow has increased more than 3-fold (Hansen, 2000). It is closely related to increased DMI and increased metabolic heat

Received February 27, 2013.

Accepted August 21, 2013.

${ }^{1}$ Corresponding author: w.heuwieser@fu-berlin.de production (Kadzere et al., 2002). Heat production and congestion, in combination with compromised cooling capability because of environmental conditions, causes the heat load in cows to increase to the point that body temperature rises (Burfeind et al., 2012) and DMI and milk production decline (Wilson et al., 1998; Ravagnolo et al., 2000; West et al., 2003). Particularly in hot seasons, cows are metabolically challenged to emit excess body heat (Purwanto et al., 1990; West, 2003). Maintenance expenditures at $35^{\circ} \mathrm{C}$ increase by $20 \%$ over thermoneutral conditions of $16^{\circ} \mathrm{C}$ or lower (NRC, 1981). These processes can cause suboptimal reproductive performance of dairy cows, such as a decrease in conception rate during the hot season by 20 to $30 \%$ compared with the winter season (De Rensis et al., 2002) and important economic losses (Collier et al., 2006). Climate conditions may be a major contributing factor to the low fertility of dairy cows during summer months, especially in high-yielding cows (Kadzere et al., 2002).

Heat stress is becoming increasingly important because an increase in milk yield is related to a decrease in heat tolerance (Berman et al., 1985; West, 2003) and milk yield is expected to further increase (Hansen, 2000; van Arendonk and Liinamo, 2003). Accordingly, associations between heat stress, milk yield, and the effect of heat stress on the reproductive performance of dairy cows has become an important issue (Kadzere et al., 2002). The majority of studies about heat stress in livestock have been conducted in tropical or subtropical areas or during hot climate conditions (e.g., Florida, Mexico, southwest United States) because the negative effects are obvious in these climates. However, a dearth of information exists from moderate climates in the temperate latitudes (e.g., central Europe, northern United States, Canada), although extreme temperatures can occur in summer months (Alcamo et al., 2007). Furthermore, changes in the moderate climates in the temperate latitudes have been anticipated (Menzel et al., 2006; Alcamo et al., 2007).

Most of the studies investigating heat stress obtained meteorological data from a meteorological sta- 
tions located in the vicinity of the study sites, but the value of information from weather stations to augment dairy records is not known (Ravagnolo et al., 2000). As reviewed by Silanikove (2000), cows release heat and humidity via convection, conduction, and radiation through expired air and through excrement to the environment. Evaporative water loss can be up to 1.5 $\mathrm{kg} / \mathrm{h}$ per cow (Berman et al., 1985), and heat production of cows exposed to $35^{\circ} \mathrm{C}(141.8 \mathrm{kcal} / \mathrm{kg})$ is $13.9 \%$ higher than that of cows kept at $20^{\circ} \mathrm{C}(124.5 \mathrm{kcal} / \mathrm{kg}$; Robinson et al., 1986). Recently, it has been demonstrated that a trend exists in the dairy industry toward fewer and larger dairy farms housing more cows under one roof (Winsten et al., 2010), which might increase the risk of suboptimal climate conditions. Additionally, heat is often released by radiation from machinery located in the barns and humidity is released through cleaning processes. Obviously, all these factors can lead to considerably different climate conditions in confinement systems compared with those of a meteorological station recording outdoor data.

Therefore, the objectives of the study were to compare the climate conditions of dairy freestall facilities with the climate recorded from the closest official meteorological station. Specifically, we set out (1) to compare ambient temperature (AT), relative humidity (RH), and temperature-humidity index (THI) measured over a period of 24 mo from 1 barn with the climate obtained from the closest official meteorological station, (2) to compare AT, RH, and THI from different locations within 1 barn, and (3) to compare the climate conditions measured onsite at 7 different barns with data obtained from the closest official meteorological station.

\section{Data Collection}

The first and the second experiment were conducted simultaneously on a commercial dairy farm in SachsenAnhalt, Germany (barn 1), from May 2010 to May 2012. The herd consisted of 1,150 Holstein dairy cows with an average milk production of $10,124 \mathrm{~kg}$ (4.1\% fat, $3.4 \%$ protein). The barn was positioned in a northeast-southwest orientation with open ventilation and a mechanical fan system. Sixty fans were installed above the stalls and controlled manually by the farm manager. All cows were housed in a freestall facility with slatted floors and freestalls equipped with rubber mats. Three weeks before the expected date of calving, cows were housed in a close-up pen until first milking. This outdoor pen was covered by a roof attached to the outdoor wall of the main building with 2 open sides and a deep-bedded straw pack. Fresh cows were kept in a fresh cow pen until 5 DIM. From 5 DIM onward, cows were grouped in the high-yielding pen depending on lactation and reproductive status. Lactating cows were milked 3 times/d and kept in the holding area for approximately $0.5 \mathrm{~h}$ each before milking. The fresh cow and high-yielding pens, as well as the holding area, were located in the main barn, whereas the fresh cow pen was located nearby an exterior wall with an additional fresh air supply. The high-yielding pen and the holding area were located side by side with free air circulation.

Ambient temperature and $\mathrm{RH}$ within barn 1 were recorded using 4 Tinytag Plus II loggers (Germini Loggers Ltd., Chichester, UK) secured in the middle alley of the different pens at beams $3 \mathrm{~m}$ from the ground at 4 different locations (i.e., close-up pen, fresh cow pen, high-yielding pen, holding area) within the barn. These loggers measured AT from -25 to $85^{\circ} \mathrm{C}$ with an accuracy of $\pm 0.3^{\circ} \mathrm{C}$ and a resolution of $0.01^{\circ} \mathrm{C}$ and $\mathrm{RH}$ from 0 to $100 \%$ with an accuracy of $\pm 3 \%$ and a resolution of $0.3 \%$. These data were recorded hourly and loggers were calibrated by the manufacturer at the beginning and the end of the study and accuracy was checked. Additionally, AT and $\mathrm{RH}$ recorded at the same times were obtained from a meteorological station located $18 \mathrm{~km}$ east of the barn. Ambient temperature and $\mathrm{RH}$ data were used to calculate the THI according to the equation reported by Kendall and Webster (2009):

$$
\begin{aligned}
& \mathrm{THI}=(1.8 \times \mathrm{AT}+32)-[(0.55-0.0055 \times \mathrm{RH}) \\
&\times(1.8 \times \mathrm{AT}-26)] .
\end{aligned}
$$

In experiment 1, climate data were collected from barn 1, positioned in the high-yielding pen, and compared with the climate data collected from the official meteorological station from May 2010 to May 2012. In experiment 2, climate data were collected from the 4 different locations within barn 1 and compared with each other from May 2010 to February 2011. In experiment 3 , climate data were collected from 7 different barns of 6 different commercial dairy farms in Brandenburg and Sachsen-Anhalt, Germany. These data were compared with the climate data collected from the closest corresponding official meteorological stations for the period from June 2012 to October 2012. Loggers and position of the loggers were identical to experiment 1. Detailed information for barns 2 to 7 are summarized in Table 1.

\section{Statistical Analyses}

Data from the onsite climate loggers and from the official meteorological station were downloaded into Excel spreadsheets (Office 2010, Microsoft Deutschland GmbH, Munich, Germany) and analyzed using SPSS for Windows (Version 19.0, SPSS Inc., IBM, Ehningen, 
Table 1. Housing information for the 7 barns investigated (barns 4 and 5 were located on the same study site)

\begin{tabular}{|c|c|c|c|c|c|c|c|}
\hline Parameter & Barn 1 & Barn 2 & Barn 3 & Barn 4 & Barn 5 & Barn 6 & Barn 7 \\
\hline Cows inside the barn (no.) & 900 & 250 & 50 & 80 & 200 & 170 & 150 \\
\hline Geographical position & $\begin{array}{c}51^{\circ} 77^{\prime} \mathrm{N} \\
12^{\circ} 91^{\prime} \mathrm{E}\end{array}$ & $\begin{array}{l}51^{\circ} 89^{\prime} \mathrm{N} \\
12^{\circ} 89^{\prime} \mathrm{E}\end{array}$ & $\begin{array}{c}51^{\circ} 88^{\prime} \mathrm{N} \\
12^{\circ} 90^{\prime} \mathrm{E}\end{array}$ & $\begin{array}{c}52^{\circ} 70^{\prime} \mathrm{N} \\
13^{\circ} 66^{\prime} \mathrm{E}\end{array}$ & $\begin{array}{c}52^{\circ} 70^{\prime} \mathrm{N} \\
13^{\circ} 66^{\prime} \mathrm{E}\end{array}$ & $\begin{array}{c}52^{\circ} 68^{\prime} \mathrm{N} \\
12^{\circ} 88^{\prime} \mathrm{E}\end{array}$ & $\begin{array}{c}52^{\circ} 93^{\prime} \mathrm{N}, \\
13^{\circ} 02^{\prime} \mathrm{E}\end{array}$ \\
\hline Meteorological station (km) & 18 & 21 & 22 & 13 & 13 & 9 & 14 \\
\hline \multicolumn{8}{|l|}{ Ventilation } \\
\hline Mechanical & $\mathrm{x}$ & & & $\mathrm{x}$ & $\mathrm{x}$ & & $\mathrm{x}$ \\
\hline \multicolumn{8}{|l|}{ Flooring } \\
\hline Slatted & $\mathrm{x}$ & & & $\mathrm{x}$ & & & $\mathrm{x}$ \\
\hline Deep straw & & & & & & $\mathrm{x}$ & \\
\hline Concrete & & $\mathrm{x}$ & $\mathrm{x}$ & & $\mathrm{x}$ & & \\
\hline \multicolumn{8}{|l|}{ Bedding } \\
\hline Rubber mats & $\mathrm{x}$ & & & $\mathrm{x}$ & $\mathrm{x}$ & & \\
\hline Deep straw & & $\mathrm{x}$ & $\mathrm{x}$ & & & $\mathrm{x}$ & $\mathrm{x}$ \\
\hline Milkings per day (no.) & 3 & 3 & 3 & 3 & 3 & 2 & 2 \\
\hline
\end{tabular}

Germany). In addition, daily and monthly averages of $\mathrm{AT}$ and RH means were calculated. According to Ravagnolo et al. (2000), days of heat stress were defined as days with a mean THI $\geq 72$. The relationship between climate data of the official meteorological stations and the climate loggers, as well as the relationship between the 4 locations in the barn, were assessed using Pearson correlation.

In experiment 1 , differences between daily $\mathrm{AT}, \mathrm{RH}$, and THI of the official meteorological station and the climate loggers were assessed using a paired $t$-test. Number of days with an average THI $\geq 72$ and days with a minimum of $1 \mathrm{~h}$ averaging THI $\geq 72$ were compared between the official meteorological station and the high-yielding pen; the statistical significance was estimated using a Chi-squared test. Agreement between climate data of the official meteorological station and the climate logger was analyzed graphically using the method of Bland and Altman (1986). For each climate variable, the difference between the official meteorological station and the climate logger was calculated and plotted against their mean.

In experiment 2 , differences between daily $\mathrm{AT}, \mathrm{RH}$, and THI of the 4 different locations in the barn were analyzed as a repeated measure ANOVA using the nonparametric Kruskal-Wallis one-way analysis procedure in SPSS because data did not follow a normal distribution. Number of days with an average THI $\geq 72$ and days with a minimum of $1 \mathrm{~h}$ averaging THI $\geq 72$ were compared between the 4 different locations; the statistical significance was estimated by using a Chi-squared test.

In experiment 3 , differences between daily $\mathrm{AT}, \mathrm{RH}$, and THI of the official meteorological stations and the climate loggers in the 7 different barns were assessed using a paired $t$-test. Number of days with an average THI $\geq 72$ and days with a minimum of $1 \mathrm{~h}$ averag- ing THI $\geq 72$ were compared between climate loggers of the 7 different barns and the corresponding official meteorological station; the statistical significance was estimated by using a Chi-squared test.

\section{Experiment 1}

Coefficients of correlation between daily averages of $\mathrm{AT}, \mathrm{RH}$, and THI measured in the barn and at the official meteorological station were $\mathrm{r}=0.93(\mathrm{n}=756$; $P<0.01), 0.85$ (n $=756 ; P<0.01)$, and 0.92, (n $=756 ; P<0.01)$, respectively. Overall, AT was 6.4 $\pm 3.6^{\circ} \mathrm{C}$ higher in the barn $\left(15.9 \pm 5.5^{\circ} \mathrm{C}\right)$ compared with the official meteorological station $\left(9.5 \pm 8.2^{\circ} \mathrm{C}\right.$, $\mathrm{n}=756, P<0.01)$. The $\mathrm{RH}$ was $0.2 \pm 7.2 \%$ higher at the official meteorological station $(74.9 \pm 12.9 \%)$ compared with the barn $(75.1 \pm 8.4 \%, \mathrm{n}=756, P<$ $0.01)$. The THI was $11.1 \pm 6.5$ higher in the barn $(60.1$ $\pm 8.5)$ than at the official meteorological station (48.9 $\pm 13.3, \mathrm{n}=756, P<0.01)$. Number of days averaging THI $\geq 72$ were $64(8.4 \%)$ and $4(0.005 \%)$ of the 756 experimental $\mathrm{d}$ in the barn and at the official meteorological station, respectively $(P<0.01)$. Days with an average THI $\geq 72$ were spread over 9 (June-August 2010, May-September 2011, May 2012) and 2 mo (July 2010, September 2011) for the onsite loggers and the official meteorological station, respectively. Number of days with a minimum of $1 \mathrm{~h}$ averaging THI $\geq 72$ were $162(21.4 \%)$ and $75(9.9 \%)$ of the 756 experimental $d$ in the barn and at the official meteorological station, respectively $(P<0.01)$.

The difference calculated between AT measured at the official meteorological station and AT measured onsite during cold climate conditions (October-February) was higher compared with hot climate conditions (May-August; Figure 1A). Higher AT in the barn during the winter months may be a result of the heat 
production of the cows, which increases during cold climate conditions (Robinson et al., 1986). Higher AT in the barn during summer months may be a result of a poor ventilation and heat congestion usually caused by structural deficiencies or insufficient use of fans and sprinklers (Collier et al., 2006). Also, the difference calculated between THI at the official meteorological station and THI measured onsite during cold climate conditions (October-February) was higher compared with hot climate conditions (May-August; Figure 1C). The RH measured during cold climate conditions (October-February) was higher at the official meteorological station compared with the onsite measurement. The RH measured during hot climate conditions (MayAugust) was higher onsite compared with the official meteorological station (Figure 1B). Evaporative water loss of up to $1.5 \mathrm{~kg} / \mathrm{h}$ of dairy cows (Berman et al., 1985), on top of poor ventilation, might contribute to the high RH inside the barn during summer months. High precipitation rate during autumn and winter is assumed to cause higher RH during winter months at the official meteorological station than inside the barn. As demonstrated with the Bland-Altman plots, AT and THI exceed the upper end of the 95\% CI for an AT $<10^{\circ} \mathrm{C}$ and THI $<50$, indicating that $\mathrm{AT}$ and THI were higher inside the barn compared with the official meteorological station during cold climate conditions (Figure 1D and F).

\section{Experiment 2}

Coefficients of correlation between daily averages of AT, RH, and THI between the 4 different locations in the barn are summarized in Table 2. Relative humidity and resulting THI were highest in the holding area and the adjacent high-yielding pen. Lowest THI was detected in the close-up pen, which was located outdoors, and the fresh cow pen, which was located nearby an exterior wall with an additional fresh air supply. Kruskal-Wallis one-way analysis was used to classify homogeneous subgroups of the 4 different locations in the barn for the different climate variables. As demonstrated in Table 3 for AT and THI, the high-yielding pen and the holding area were assigned to one subgroup, whereas the close-up pen and the fresh cow pen were assigned to one subgroup with comparable climate conditions. For RH subgroups did not exist. Number of days with an average THI $\geq 72$ were 44, 36, 26, and 23 for the highyielding pen, holding area, close-up pen, and fresh cow pen, respectively $(\mathrm{n}=270 ; P=0.06)$. Number of days with a minimum of $1 \mathrm{~h}$ averaging THI $\geq 72$ were 78 , 74,58 , and 48 for the high-yielding pen, holding area, close-up pen, and fresh cow pen, respectively $(\mathrm{n}=270$; $P=0.06)$. In all locations, days with an average THI $\geq 72$ were spread over a period of 3 mo (June-August 2010). Because of condensation on the climate loggers due to technical design, data were lost for $7,771,322$, and 2,007 out of 6,449 hourly measured $\mathrm{RH}$ values and resulting THI values for the high-yielding pen, holding area, close-up pen, and fresh cow pen, respectively.

These observations illustrate that climate conditions are not uniform across a dairy farm and microclimates can exist due to different functions of pens, construction characteristics, and environmental conditions. Our study provided data to support an earlier postulation that the holding pen, in particular, is a location of intensive heat stress (Collier et al., 2006) that requires effective heat abatement measures. In locations in the barn with high evaporation and consequently high-THI conditions, effective discharge of this hot and humid air should be provided to prevent heat stress in the barn.

\section{Experiment 3}

Coefficients of correlation between daily averages of $\mathrm{AT}, \mathrm{RH}$, and THI, as well as mean AT, RH, and THI between the 7 different barns and the corresponding official meteorological station, are summarized in Table 4. Number of days with an average THI $\geq 72$ and number of days with a minimum of $1 \mathrm{~h}$ averaging THI $\geq 72$ are summarized in Table 5 . In all barns, days averaging THI $\geq 72$ were spread over a period of 4 mo (JuneSeptember 2012). The geographical distances between the 7 barns and the closest corresponding official meteorological station ranged from 9 to $22 \mathrm{~km}$ (Table 1) with a mean distance of $15.71 \pm 4.75 \mathrm{~km}$. To exclude a relationship between the geographical distance and the differences of climate data between the 7 barns and the closest official meteorological station, Pearson correlations were assessed. The coefficients of correlation between the geographical distance and the mean difference of AT, RH, and THI between the 7 barns and the closest official meteorological station were $\mathrm{r}=0.38(\mathrm{n}$ $=7 ; P=0.40), 0.59(\mathrm{n}=7 ; P=0.16)$, and $0.40,(\mathrm{n}=$ $7 ; P=0.37)$, respectively.

In the present study, barns with different construction types and environmental conditions were included. Barn 5 showed the best climate conditions, with lowest AT, RH, and THI, and barn 7 showed the poorest climate conditions, with highest AT, RH, and THI. Interestingly, both barns were newly constructed (2008 and 2000) with high ceilings $(8 \mathrm{~m})$ and natural and mechanical ventilation. These results suggest that even modern barns with mechanical ventilation do not guarantee good climate conditions inside. Besides structural conditions, many factors (e.g., stocking rate, location of the barn, prevailing wind direction relative to the floor plan) influencing climate conditions inside the barn 
A

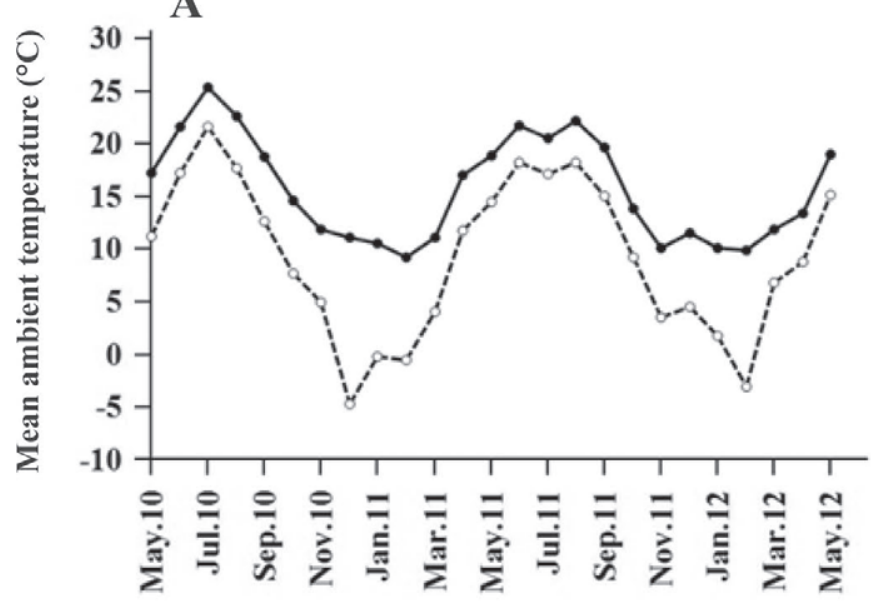

B

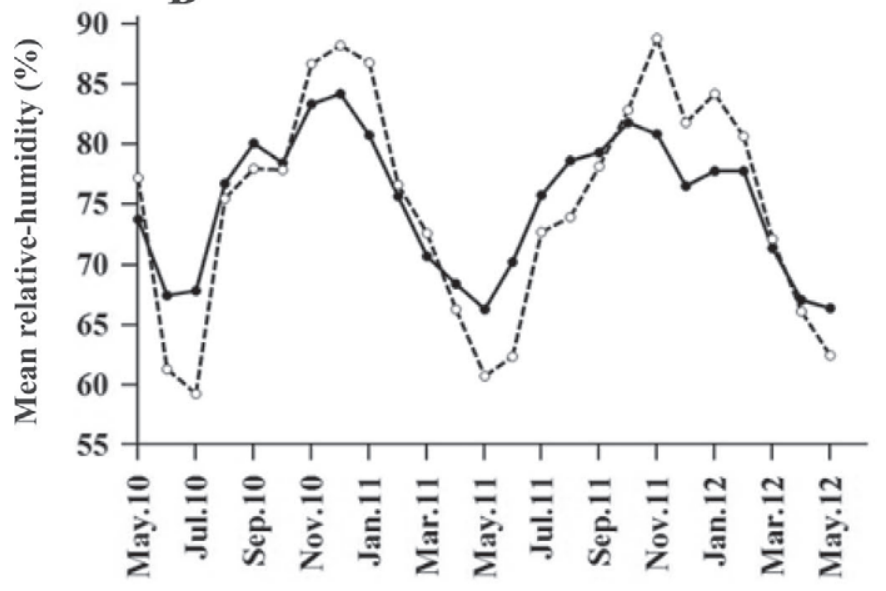

C

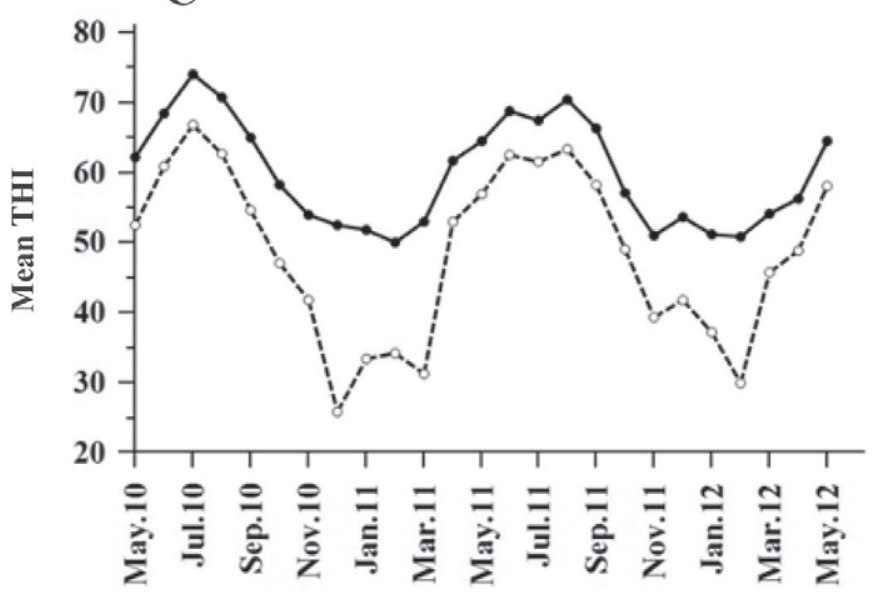

Month of study

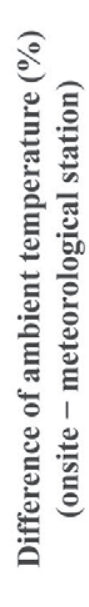

D

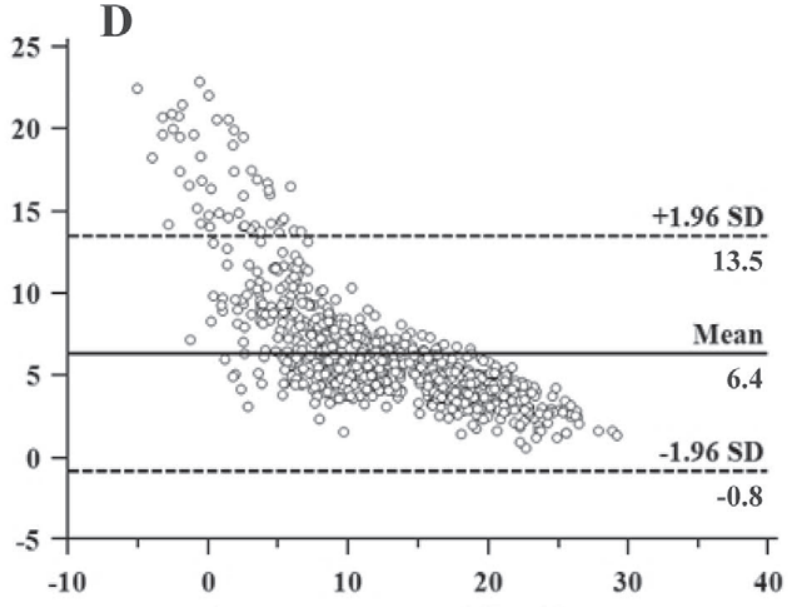

Mean ambient temperature $\left({ }^{\circ} \mathrm{C}\right)$ of 2 measurements (onsite and meteorological station) E

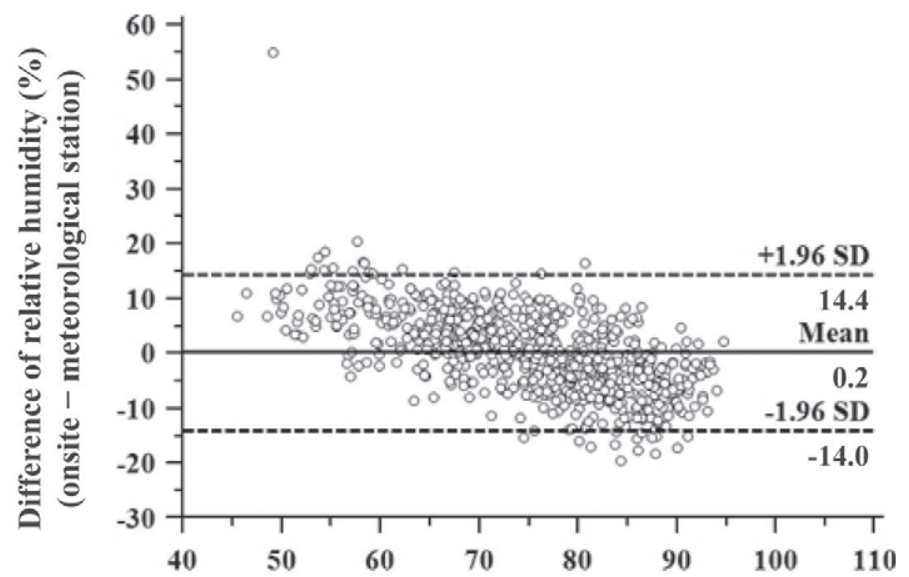

Mean relative humidity (\%) of the 2 measurements (onsite and meteorological station)

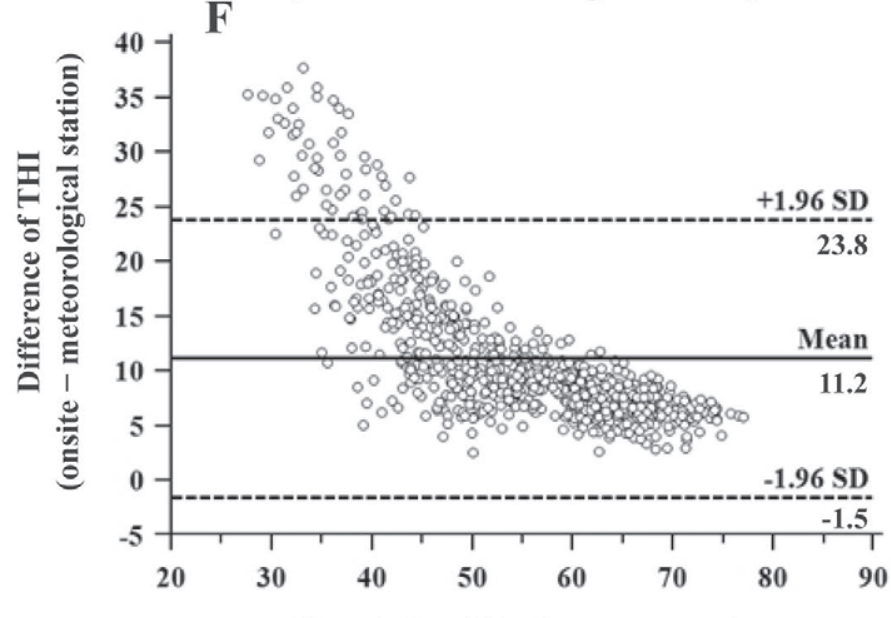

Mean THI of the 2 measurements (onsite and meteorological station)

Figure 1. Monthly ambient temperature, relative humidity, and temperature-humidity index (THI) measured in the barn (-) and at the official meteorological station (--; A-C) and Bland-Altman plots (D-F) displaying the differences between the barn and official meteorological station using daily means. 
Table 2. Correlations for ambient temperature, relative humidity, and temperature-humidity index considering 4 different locations in one barn $(\mathrm{n}=270$ experimental days)

\begin{tabular}{|c|c|c|c|c|}
\hline \multirow[b]{2}{*}{ Variable } & \multicolumn{4}{|c|}{ Location } \\
\hline & $\begin{array}{l}\text { High-yielding } \\
\text { pen }\end{array}$ & $\begin{array}{l}\text { Close-up } \\
\text { pen }\end{array}$ & $\begin{array}{l}\text { Fresh cow } \\
\text { pen }\end{array}$ & $\begin{array}{c}\text { Holding } \\
\text { area }\end{array}$ \\
\hline \multicolumn{5}{|l|}{ Temperature $\left({ }^{\circ} \mathrm{C}\right)$} \\
\hline High-yielding pen & & $0.95^{*}$ & $0.96^{*}$ & $0.98^{*}$ \\
\hline Close-up pen & $0.95^{*}$ & & $0.98^{*}$ & $0.97^{*}$ \\
\hline Fresh cow pen & $0.96^{*}$ & $0.98^{*}$ & & $0.99^{*}$ \\
\hline Holding area & $0.98^{*}$ & $0.97^{*}$ & $0.99^{*}$ & \\
\hline \multicolumn{5}{|l|}{ Relative humidity (\%) } \\
\hline High-yielding pen & & $0.88^{*}$ & $0.88^{*}$ & $0.88^{*}$ \\
\hline Close-up pen & $0.88^{*}$ & & $0.92 *$ & $0.86^{*}$ \\
\hline Fresh cow pen & $0.88^{*}$ & $0.92^{*}$ & & $0.93^{*}$ \\
\hline Holding area & $0.88^{*}$ & $0.86^{*}$ & $0.93^{*}$ & \\
\hline \multicolumn{5}{|c|}{ Temperature-humidity index } \\
\hline High-yielding pen & & $0.94^{*}$ & $0.95^{*}$ & $0.97^{*}$ \\
\hline Close-up pen & $0.94^{*}$ & & $0.98^{*}$ & $0.96^{*}$ \\
\hline Fresh cow pen & $0.95^{*}$ & $0.98^{*}$ & & $0.98^{*}$ \\
\hline Holding area & $0.97^{*}$ & $0.96^{*}$ & $0.98^{*}$ & \\
\hline
\end{tabular}

$* P<0.01$.

cannot always be anticipated or objectively assessed. Even though mechanical ventilation was operating inside barn 1, the THI was significantly higher inside that barn than at the official meteorological station for the whole study period. Without mechanical ventilation, the THI inside the barn and the difference to the meteorological station may have been even higher. These results indicate that climate data obtained from a meteorological station is not adequate for barns with or without mechanical ventilation. Our data provide the first evidence that climate data should be established at the farm level to develop preventive strategies to avoid heat stress for dairy cows housed indoors.

Unlike most of the studies researching heat stress, our data were collected from moderate climates in the temperate latitudes in central Europe. Compared with tropical or subtropical areas, such geographical regions experience discriminative seasons with high variation of climate conditions between the winter and summer months. Interestingly, cows acclimated to cold climate conditions showed higher reactions (heat production, respiration rate) to heat stress than cows acclimated to warmer climate conditions (Robinson et al., 1986). In the present study, we observed considerable fluctuation in AT and THI in relatively short periods measured inside the barns. In future studies, it should be determined if heat stress might have a greater effect on dairy cows in temperate latitudes than on cows in tropical or subtropical areas that are accustomed to warmer climate conditions.

A high percentage $(58 \%)$ of dairy cows in Germany are housed indoors throughout the year, whereas the remaining cows have some access to pasture (on average 24 wk/yr; Gurrath, 2011). In most cases, however, access to pasture is limited to only few hours per day and milking and feeding are conducted in the barn. In the present study, climate conditions were exclusively determined inside the barn. Further research is warranted to determine if climate conditions in grazing livestock differ from climate data of a meteorological station located in the vicinity of the study sites.

In the present study, AT and resulting THI measured in the barn over 2 yr were significantly higher than those measured at the official meteorological station. Most importantly, the number of days averaging THI $\geq 72$, defined as days of heat stress (Ravagnolo et al., 2000), were significantly higher inside the barn compared with the official meteorological station. In a

Table 3. Mean ambient temperature, relative humidity $(\mathrm{RH})$, and temperature-humidity index (THI) considering 4 different locations in one barn $(n=270$ experimental days $)$

\begin{tabular}{lccc}
\hline Location & Temperature $\left({ }^{\circ} \mathrm{C}\right)$ & RH $(\%)$ & THI \\
\hline High-yielding pen & $17.2 \pm 5.6^{\mathrm{b}}$ & $76.9 \pm 8.0$ & $62.1 \pm 8.6^{\mathrm{b}}$ \\
Close-up pen & $13.2 \pm 8.9^{\mathrm{a}}$ & $77.9 \pm 12.8$ & $55.3 \pm 14.1^{\mathrm{a}}$ \\
Fresh cow pen & $14.2 \pm 6.9^{\mathrm{a}}$ & $81.3 \pm 12.2$ & $58.0 \pm 11.5^{\mathrm{a}}$ \\
Holding area & $16.6 \pm 5.5^{\mathrm{b}}$ & $84.1 \pm 8.7$ & $61.3 \pm 8.9^{\mathrm{b}}$ \\
\hline
\end{tabular}

${ }^{\mathrm{a}, \mathrm{b}}$ Means within a column with different superscripts differ $(P<0.01)$. 
Table 4. Mean ambient temperature, relative humidity, and temperature-humidity index onsite and at the closest official meteorological station and correlations considering 7 barns

\begin{tabular}{|c|c|c|c|c|c|c|c|}
\hline \multirow[b]{2}{*}{ Variable } & \multicolumn{7}{|c|}{ Barn } \\
\hline & 1 & 2 & 3 & 4 & 5 & 6 & 7 \\
\hline In the barn & $20.5 \pm 3.0$ & $18.1 \pm 4.0$ & $19.0 \pm 3.6$ & $17.9 \pm 3.6$ & $17.3 \pm 3.9$ & $18.6 \pm 3.2$ & $21.1 \pm 2.4$ \\
\hline At the station & $16.2 \pm 4.4$ & $16.2 \pm 4.4$ & $16.2 \pm 4.4$ & $15.8 \pm 3.9$ & $15.8 \pm 3.9$ & $16.4 \pm 4.1$ & $17.3 \pm 3.0$ \\
\hline Difference & $4.3 \pm 2.0^{*}$ & $1.9 \pm 1.7^{*}$ & $2.8 \pm 1.8^{*}$ & $2.1 \pm 0.8^{*}$ & $1.4 \pm 0.6^{*}$ & $2.2 \pm 1.2^{*}$ & $3.8 \pm 0.8^{*}$ \\
\hline Correlation & $0.91^{*}$ & $0.92^{*}$ & $0.91^{*}$ & $0.98^{*}$ & $0.99^{*}$ & 0.97 & 0.98 \\
\hline At the station & $72.1 \pm 9.5$ & $72.1 \pm 9.5$ & $72.1 \pm 9.5$ & $76.9 \pm 8.3$ & $76.9 \pm 8.3$ & $75.8 \pm 9.4$ & $76.6 \pm 7.3$ \\
\hline Difference & $3.9 \pm 5.9^{*}$ & $5.6 \pm 5.0^{*}$ & $3.1 \pm 5.0^{*}$ & $2.8 \pm 3.9^{*}$ & $1.7 \pm 2.7^{*}$ & $4.8 \pm 5.5^{*}$ & $2.6 \pm 6.1^{*}$ \\
\hline Correlation & $0.79^{*}$ & $0.85^{*}$ & $0.85^{*}$ & $0.89^{*}$ & $0.96^{*}$ & $0.36^{*}$ & $0.72^{*}$ \\
\hline \multicolumn{8}{|c|}{ Temperature-humidity index } \\
\hline In the barn & $67.3 \pm 4.7$ & $63.3 \pm 6.0$ & $64.6 \pm 5.3$ & $63.4 \pm 5.8$ & $61.9 \pm 6.0$ & $64.5 \pm 5.1$ & $68.5 \pm 3.8$ \\
\hline At the station & $60.2 \pm 6.3$ & $60.2 \pm 6.3$ & $60.2 \pm 6.3$ & $59.6 \pm 6.0$ & $59.6 \pm 6.0$ & $60.5 \pm 6.1$ & $62.0 \pm 4.5$ \\
\hline Difference & $7.0 \pm 2.1^{*}$ & $3.0 \pm 1.2^{*}$ & $4.3 \pm 1.7^{*}$ & $3.7 \pm 1.0^{*}$ & $2.3 \pm 0.8^{*}$ & $4.0 \pm 1.5^{*}$ & $6.5 \pm 1.3^{*}$ \\
\hline
\end{tabular}

$* P<0.01$

Table 5. Number of days with a mean temperature-humidity index (THI) $\geq 72$ and number of days with a minimum of $1 \mathrm{~h}$ averaging THI $\geq 72$ onsite and at the closest official meteorological station

\begin{tabular}{|c|c|c|c|c|c|c|c|}
\hline \multirow[b]{2}{*}{ Barn } & \multicolumn{3}{|c|}{$\begin{array}{l}\text { Days with } \\
\text { THI } \geq 72\end{array}$} & \multicolumn{3}{|c|}{$\begin{array}{c}\text { Days with minimum } 1 \mathrm{~h} \\
\mathrm{THI} \geq 72\end{array}$} & \multirow[b]{2}{*}{$\mathrm{n}$} \\
\hline & $\begin{array}{l}\text { In the } \\
\text { barn }\end{array}$ & $\begin{array}{l}\text { At the } \\
\text { meteorological } \\
\text { station }\end{array}$ & $P$-value & $\begin{array}{l}\text { In the } \\
\text { barn }\end{array}$ & $\begin{array}{l}\text { At the } \\
\text { meteorological } \\
\text { station }\end{array}$ & $P$-value & \\
\hline 1 & 18 & 1 & $<0.01$ & 60 & 31 & $<0.01$ & 123 \\
\hline 2 & 10 & 1 & $<0.01$ & 40 & 31 & 0.20 & 123 \\
\hline 3 & 9 & 1 & $<0.01$ & 35 & 31 & 0.56 & 123 \\
\hline 4 & 7 & 1 & 0.03 & 25 & 20 & 0.41 & 119 \\
\hline 5 & 5 & 1 & 0.09 & 27 & 20 & 0.25 & 119 \\
\hline 6 & 10 & 7 & 0.21 & 37 & 32 & 0.48 & 123 \\
\hline 7 & 18 & 1 & $<0.01$ & 56 & 22 & $<0.01$ & 99 \\
\hline
\end{tabular}

multilocation trial including 7 barns, the AT and the THI measured over 4 mo were also significantly higher than at the official meteorological station. These results indicate that, in studies which obtain climate data from a meteorological station, heat stress is underestimated both in magnitude and duration. To assess heat stress accurately, onsite measurement of relevant climate data is mandatory.

\section{ACKNOWLEDGMENTS}

We thank the collaborating dairy farms for the possibility to collect the climate data. Furthermore, we thank the German Weather Service for providing climate data. Laura-Kim Schüller was partly funded by the Dr. Dr. h. c. Karl Eibl-Foundation of the Neustadt a.d. Aisch A.I. Association (Neustadt a.d. Aisch, Germany) and Tiergyn e.V. (Berlin, Germany).

\section{REFERENCES}

Alcamo, J., J. M. Moreno, B. Nováky, M. Bindi, R. Corobov, R. J. N., Devoy, C. Giannakopoulos, E. Martin, J. E. Olesen, and A. Shvidenko. 2007. Impacts, adaptation and vulnerability. Pages 541580 in Contribution of Working Group II to the Fourth Assessment Report of the Intergovernmental Panel on Climate Change. Cambridge University Press, Cambridge, UK

Berman, A., Y. Folman, M. Kaim, M. Mamen, Z. Herz, D. Wolfenson, A. Arieli, and Y. Graber. 1985. Upper critical temperatures and forced ventilation effects for high-yielding dairy cows in a subtropical climate. J. Dairy Sci. 68:1488-1495.

Bland, J. M., and D. G. Altman. 1986. Statistical methods for assessing agreement between two methods of clinical measurement. Lancet i:307-310.

Burfeind, O., V. S. Suthar, and W. Heuwieser. 2012. Effect of heat stress on body temperature in healthy early postpartum dairy cows. Theriogenology 78:2031-2038.

Collier, R. J., G. E. Dahl, and M. J. VanBaale. 2006. Major advances associated with environmental effects on dairy cattle. J. Dairy Sci. 89:1244-1253.

De Rensis, F., P. Marconi, T. Capelli, F. Gatti, F. Facciolongo, S. Franzini, and R. J. Scaramuzzi. 2002. Fertility in postpartum dairy cows in winter or summer following estrus synchronization and 
fixed time AI after the induction of an $\mathrm{LH}$ surge with $\mathrm{GnRH}$ or hCG. Theriogenology 58:1675-1687.

Gurrath, P. 2011. Rinderbestand und Haltung. Pages 24-25 in Landwirtschaft auf einen Blick. Statistisches Bundesamt, Wiesbaden, Germany.

Hansen, L. B. 2000. Consequences of selection for milk yield from a geneticist's viewpoint. J. Dairy Sci. 83:1145-1150.

Kadzere, C. T., M. R. Murphy, N. Silanikove, and E. Maltz. 2002. Heat stress in lactating dairy cows: A review. Livest. Prod. Sci. 77:59-91.

Kendall, P. E., and J. R. Webster. 2009. Season and physiological status affects the circadian body temperature rhythm of dairy cows. Livest. Sci. 125:155-160.

Menzel, A., T. H. Sparks, N. Estrella, E. Koch, A. Aasa, R. Ahas, K. Alm-Kübler, P. Bissolli, O. Braslavská, A. Briede, F. M. Chmielewski, Z. Crepinsek, Y. Curnel, Å. Dahl, C. Defila, A. Donnelly, Y. Filella, K. Jatczak, F. Mage, A. Mestre, Ø. Nordli, J. Penuelas, P. Pirinen, V. RemiSová, H. Scheifinger, M. Striz, A. Susnik, A. J. H. Van Vliet, F.-E. Wielgolaski, S. Zach, and A. Zust. 2006. European phenological response to climate change matches the warming pattern. Glob. Change Biol. 12:1969-1976.

NRC. 1981. Effect of Environment on Nutrient Requirements of Domestic Animals. Natl. Acad. Press, Washington, DC.

Purwanto, B. P., Y. Aboa, R. Sakamotoa, F. Furumotoa, and S. Yamamoto. 1990. Diurnal patterns of heat production and heart rate under thermoneutral conditions in Holstein Friesian cows differing in milk production. J. Agric. Sci. 114:139-142.
Ravagnolo, O., I. Misztal, and G. Hoogenboom. 2000. Genetic component of heat stress in dairy cattle, development of heat index function. J. Dairy Sci. 83:2120-2125.

Robinson, J. B., D. R. Ames, and G. A. Milliken. 1986. Heat-production of cattle acclimated to cold, thermoneutrality and heat when exposed to thermoneutrality and heat stress. J. Anim. Sci. 62:1434-1440.

Silanikove, N. 2000. Effects of heat stress on the welfare of extensively managed domestic ruminants. Livest. Prod. Sci. 67:1-18.

van Arendonk, J. A. M., and A.-E. Liinamo. 2003. Dairy cattle production in Europe. Theriogenology 59:563-569.

West, J. W. 2003. Effects of heat-stress on production in dairy cattle. J. Dairy Sci. 86:2131-2144.

West, J. W., B. G. Mullinix, and J. K. Bernard. 2003. Effects of hot, humid weather on milk temperature, dry matter intake, and milk yield of lactating dairy cows. J. Dairy Sci. 86:232-242.

Wilson, S. J., R. S. Marion, J. N. Spain, D. E. Spiers, D. H. Keisler, and M. C. Lucy. 1998. Effects of controlled heat stress on ovarian function of dairy cattle. 1. Lactating cows. J. Dairy Sci. 81:21242131.

Winsten, J. R., C. D. Kerchner, A. Richardson, A. Lichau, and J. M. Hyman. 2010. Trends in the northeast dairy industry: Large-scale modern confinement feeding and management-intensive grazing. J. Dairy Sci. 93:1759-1769. 